This document was prepared in conjunction with work accomplished under Contract No. DE-AC09-96SR18500 with the U.S. Department of Energy.

This work was prepared under an agreement with and funded by the U.S. Government. Neither the U. S. Government or its employees, nor any of its contractors, subcontractors or their employees, makes any express or implied: 1 . warranty or assumes any legal liability for the accuracy, completeness, or for the use or results of such use of any information, product, or process disclosed; or 2 . representation that such use or results of such use would not infringe privately owned rights; or 3 . endorsement or recommendation of any specifically identified commercial product, process, or service. Any views and opinions of authors expressed in this work do not necessarily state or reflect those of the United States Government, or its contractors, or subcontractors. 
WSRC-STI-2008-00238

Revision 0

\section{Evaluating Effects of Neptunium on the SRS Method for Controlled-Potential Coulometric Assay of Plutonium in Sulfuric Acid Supporting Electrolyte}

Authors: Michael K. Holland and Sheldon T. Nichols

Technical Agency: Analytical Laboratories Project (ALP)

Technical Task Request Number: 2008-INNP-FHL-00001

May 9, 2008 
WSRC-STI-2008-00238

Revision 0

\section{REVIEW AND APPROVAL}

Author:

Michael K. Holland, Chemist

Analytical Laboratories Project

Signature on File

Signature

2008-May-08

Sheldon T. Nichols, Chemist

Analytical Laboratories Project

Signature on File

Signature

2008-May-09

$\frac{\text { Signature on File }}{\text { Signature }} \frac{\text { 2008-May-09 }}{\text { Date }}$

Independent Technical Reviewers:

Robin H. Young, Chemist

Analytical Laboratories Project

Signature on File

2008-May-08

Signature

Joseph V. Cordaro, Engineer

SRNL, Engineered Equipment \& Systems

[SRS Coulometer Design Agency]

Signature on File

Signature

2008-May-09

Approver:

Edward T. Sadowski, Chief Scientist

Analytical Laboratories Project

Signature on File Signature

2008-May-08

Derivative Classifier / Reviewing Official:

See Title Page

Page 1 Signature on File 


\section{$\underline{\text { Keywords }}$}

ALP Analytical Laboratories Project (SRS laboratory organization)

EES Engineered Equipment \& Systems (SRS instrument design organization in SRNL)

INN International Nuclear Nonproliferation

ISO International Organization for Standardization

MDP Method Development Plan (an ALP technical work authorization document)

SCE Saturated Calomel Electrode

SRNL Savannah River National Laboratory

SRS Savannah River Site

USQ Unreviewed Safety Question

WSRC Washington Savannah River Company

\section{Acknowledgements}

The authors gratefully acknowledge:

- Preparing of aliquots and performing of coulometric measurements by James C. Pearre, Jr., Jacob M. Gue, and Donald D. Benson, WSRC ALP.

- Measuring impurity elements in plutonium and neptunium solutions by inductively coupled plasma mass spectrometry by Perry A. Miller and Vernon D. Jones, WSRC ALP.

- Funding to evaluate the effects of neptunium and its contributions to measurement uncertainty on the coulometric assay of plutonium provided by Timothy C. Hasty, WSRC International Nuclear Nonproliferation.

These measurement services were performed as requested in technical task request 2008-INNPFHL-00001, using funding source XBK26CLAB [NN5002010 from AAPUSRK26]. ${ }^{\circledR}$

Measurement activities were controlled using measurement development plan MDP-M\&O-FHL2008-00017 and procedures L3.05-10065, L3.05-10122, L3.19-10006, and L3.19-10012. ${ }^{2-6}$

Appendices 1 and 2 contain the technical task request and the method development plan cited above. 


\begin{abstract}
$\underline{\text { Abstract }}$
A study of the impact of neptunium on the coulometric assay of plutonium in dilute sulfuric acid was performed. Weight aliquots of plutonium standard solutions were spiked with purified neptunium solution to evaluate plutonium measurement performance for aliquots with $\mathrm{Pu}: \mathrm{Np}$ ratios of 50:1, 30:1, 20:1, 15:1, and 10:1. Weight aliquots of the pure plutonium standard solution were measured as controls. Routine plutonium instrument control standards were also measured. The presence of neptunium in plutonium aliquots significantly increases the random uncertainty associated with the plutonium coulometric measurement performed in accordance with ISO12183:2005. ${ }^{7}$ However, the presence of neptunium does not appear to degrade electrode performance and conditioning as aliquots of pure plutonium that were interspersed during the measurement of the mixed Pu:Np aliquots continued to achieve the historical shortterm random uncertainty for the method. Lack of adequate control of the neptunium oxidation state is suspected to be the primary cause of the elevated measurement uncertainty and will be pursued in a future study.
\end{abstract}




\section{$\underline{\text { Introduction }}$}

At the Savannah River Site (SRS), plutonium is routinely measured by controlled-potential coulometry using an SRS-designed controlled-potential coulometer that was fabricated by the Savannah River National Laboratory - Engineered Equipment \& Systems (SRNL - EES). Plutonium measurements are performed on pure or purified plutonium samples and standards in accordance with the international procedural standard ISO 12183:2005. ${ }^{7}$ Neptunium is also measured by controlled-potential coulometry using a similar procedural protocol. However, plutonium has not been measured in the presence of neptunium above the trace-level quantities that are present as daughter products from the decay of the low abundance ${ }^{241} \mathrm{Pu}$ isotope. The potential impact of neptunium on the coulometric measurements of plutonium is of interest to WSRC International Nuclear Nonproliferation (INN) programs. This WSRC program provides MPC\&A support to the Russian nuclear processing facility in Zhelesnogorsk (formerly Krasnoyarsk-26, K-26), which occasionally measures plutonium in the present of up to $10 \%$ neptunium versus the plutonium concentration. The technical staff at the Analytical Laboratories was requested to determine the magnitude of any interference from neptunium on the routine SRS coulometric measurement of plutonium and if possible to identify any modifications to the routine methodology to eliminate the interference. This information will then be used to the extent possible to aid the laboratory at the Zhelesnogorsk facility when they periodically perform key accountability measurements on mixed plutonium-neptunium streams.

\section{Methods or Approach}

Plutonium aliquots were prepared from dissolved plutonium metal in a solution of $3 \underline{\mathrm{M}}$ Nitric acid $-1 \underline{\mathrm{M}}$ Hydrochloric acid. Each solution aliquot contained nominally fifteen (15) milligrams of plutonium, prepared on a mass basis with an uncertainty of $\sim 0.01 \%$. Plutonium aliquots were dispensed into glass coulometric measurement cells that each contained the desired quantity of dried (fumed) neptunium sulfate prepared from a purified neptunium spike solution. Plutonium solution aliquots were then twice fumed to dryness in sulfuric acid. All coulometric assay measurements were performed using the routine plutonium measurement method in $1 \underline{\mathrm{N}}(0.5 \underline{\mathrm{M}})$ sulfuric acid supporting electrolyte. 


\section{$\underline{\text { Assumptions }}$}

Only a reasonably pure neptunium spike solution would be suitable for this study. The neptunium spike solution had been prepared from dissolved neptunium oxide solid produced at the Savannah River Site. The solution had been purified in the laboratory and analyzed to verify its purity and concentration were suitable as a spike solution for this application. Results from the measurement of the purified neptunium spike solution are included in Appendix 3. Based upon knowledge of neptunium chemistry and the sequence used in the laboratory to dissolve and purify the neptunium oxide, this spike solution was anticipated to have neptunium in the $\mathrm{Np}^{4+}$, $\mathrm{NpO}_{2}{ }^{+}\left(\mathrm{Np}^{5+}\right)$, and $\mathrm{NpO}_{2}{ }^{2+}\left(\mathrm{Np}^{6+}\right)$ oxidation states, and thus assumed suitable to evaluate the potential interference from all of these neptunium ions on plutonium coulometric measurements.

This study was designed to test the potential interference of neptunium on the SRS routine method for coulometric measurement of plutonium. Sample preparation and measurement parameters were intentionally not adjusted to improve control of the neptunium oxidation state or otherwise ensure the oxidation of $\mathrm{Np}^{4+}$ ions prior to the plutonium measurement step. This study was designed to test the assumption that the reversible $\mathrm{NpO}_{2}{ }^{2+} / \mathrm{NpO}_{2}{ }^{+} \mathrm{red} / \mathrm{ox}$ couple and the $\mathrm{Np}^{4+}$ ion would not interfere significantly with the plutonium electrolysis in sulfuric acid supporting electrolyte.

\section{$\underline{\text { Discussion }}$}

This study is limited to reporting observed results from the coulometric measurement of plutonium aliquots using the routine SRS coulometric assay method on aliquots containing 0$10 \%$ added neptunium.

This report also documents the purity of the neptunium solution used to spike plutonium aliquots with the different levels of neptunium studied.

The reader is referred to a study of the coulometric measurement of plutonium in the presence of a second reversible couple (iron or neptunium) in nitric acid supporting electrolyte for related information. ${ }^{8}$ In the nitric acid supporting electrolyte, neptunium interferes, but the interference can be quantified electrochemically during sequential plutonium measurement and corrected. This study evaluated neptunium interference in nitric acid supporting electrolyte for solutions with a Pu:Np ratio of 50:1, or greater, i.e., a maximum of $2 \% \mathrm{~Np}$ versus $\mathrm{Pu}$. 


\section{$\underline{\text { Results }}$}

Results for this study are provided in Table I, below. Only a small interference, if any, had been anticipated prior to conducting this study. The observed magnitude of the interference from neptunium on the routine coulometric assay of plutonium was greater than expected.

$\underline{\text { Table I. Controlled-potential coulometric measurements of plutonium }}$

\begin{tabular}{|c|c|c|c|c|c|}
\hline Description & Aliquot Size & Recovery, \% & & Mean & RSD \% \\
\hline Pure Pu Std & $6 \mathrm{mgPu}$ & $99.99 \%$ & & & \\
\hline Pure Pu Std & $6 \mathrm{mgPu}$ & $100.01 \%$ & & & \\
\hline Pure Pu Std & $6 \mathrm{mgPu}$ & $100.00 \%$ & & & \\
\hline Pure Pu Std & $6 \mathrm{mgPu}$ & $99.78 \%$ & & & \\
\hline Pure Pu Std & $6 \mathrm{mgPu}$ & $99.92 \%$ & & $99.94 \%$ & $0.10 \%$ \\
\hline Pure Pu Std & $15 \mathrm{mgPu}$ & $99.97 \%$ & & & \\
\hline Pure Pu Std & $15 \mathrm{mgPu}$ & $99.98 \%$ & & & \\
\hline Pure Pu Std & $15 \mathrm{mgPu}$ & $100.01 \%$ & & & \\
\hline Pure Pu Std & $15 \mathrm{mgPu}$ & $100.03 \%$ & & $100.00 \%$ & $0.03 \%$ \\
\hline Pu:Np 50:1 (2\%Np vs. Pu) & $15 \mathrm{mgPu}$ & $99.94 \%$ & & & \\
\hline Pu:Np 50:1 (2\%Np vs. Pu) & $15 \mathrm{mgPu}$ & $99.93 \%$ & & & \\
\hline Pu:Np 50:1 (2\%Np vs. Pu) & $15 \mathrm{mgPu}$ & $99.89 \%$ & & & \\
\hline Pu:Np 50:1 (2\%Np vs. Pu) & $15 \mathrm{mgPu}$ & $100.21 \%$ & & $99.99 \%$ & $0.15 \%$ \\
\hline Pu:Np 30:1 (3\%Np vs. Pu) & $15 \mathrm{mgPu}$ & $101.96 \%$ & & & \\
\hline Pu:Np 30:1 (3\%Np vs. Pu) & $15 \mathrm{mgPu}$ & $99.88 \%$ & & & \\
\hline Pu:Np 30:1 (3\%Np vs. Pu) & $15 \mathrm{mgPu}$ & $99.78 \%$ & & & \\
\hline Pu:Np 30:1 (3\%Np vs. Pu) & $15 \mathrm{mgPu}$ & $99.85 \%$ & & $100.37 \%$ & $1.06 \%$ \\
\hline Pu:Np 20:1 (5\%Np vs. Pu) & $15 \mathrm{mgPu}$ & $100.60 \%$ & & & \\
\hline Pu:Np 20:1 (5\%Np vs. Pu) & $15 \mathrm{mgPu}$ & $99.71 \%$ & & & \\
\hline Pu:Np 20:1 (5\%Np vs. Pu) & $15 \mathrm{mgPu}$ & Outlier & $107.52 \%$ & & \\
\hline Pu:Np 20:1 (5\%Np vs. Pu) & $15 \mathrm{mgPu}$ & $100.59 \%$ & & $100.30 \%$ & $0.51 \%$ \\
\hline Pu:Np 15:1 (7\%Np vs. Pu) & $15 \mathrm{mgPu}$ & $100.09 \%$ & & & \\
\hline Pu:Np 15:1 (7\%Np vs. Pu) & $15 \mathrm{mgPu}$ & $99.46 \%$ & & & \\
\hline Pu:Np 15:1 (7\%Np vs. Pu) & $15 \mathrm{mgPu}$ & $100.24 \%$ & & & \\
\hline Pu:Np 15:1 (7\%Np vs. Pu) & $15 \mathrm{mgPu}$ & $102.82 \%$ & & $100.65 \%$ & $1.47 \%$ \\
\hline Pu:Np 10:1 (10\%Np vs. Pu) & $15 \mathrm{mgPu}$ & $99.45 \%$ & & & \\
\hline Pu:Np 10:1 (10\%Np vs. Pu) & $15 \mathrm{mgPu}$ & $99.87 \%$ & & & \\
\hline Pu:Np 10:1 (10\%Np vs. Pu) & $15 \mathrm{mgPu}$ & $99.74 \%$ & & & \\
\hline Pu:Np 10:1 (10\%Np vs. Pu) & $15 \mathrm{mgPu}$ & $99.63 \%$ & & $99.67 \%$ & $0.18 \%$ \\
\hline
\end{tabular}

In the plutonium coulometric measurement as performed by the Savannah River Site, plutonium samples are first pre-oxidized at $0.70 \mathrm{~V} v s$. the saturated calomel electrode (SCE) to an electrolysis current of $250 \mu \mathrm{A}$ and then reduced to a final solution potential of $0.31 \mathrm{~V}$. vs. SCE in preparation for the measurement step. It was believed that any neptunium originally present as $\mathrm{Np}^{4+}$ would have been oxidized to $\mathrm{NpO}_{2}{ }^{+}\left(\mathrm{Np}^{5+}\right)$ oxidation state prior to the plutonium measurement step during final oxidation, and would not have interfered. Most of the results support a conclusion that $\mathrm{Np}^{4+}$ is producing the increased random uncertainty. 


\section{$\underline{\text { Results, continued }}$}

Most of the plutonium measurements when neptunium was present resulted in higher than expected recoveries, which matched the model for $\mathrm{Np}^{4+}$ error source. However, the four plutonium measurements with neptunium at a $\mathrm{Pu}: \mathrm{Np}$ ratio of 10:1 yielded an unexplained low recovery of $-0.33 \%$ with a $0.18 \%, 1$-sigma random uncertainty. This anomaly will also be investigated when further studies are performed.

The controlled-potentials used to reduce and oxidize plutonium in sulfuric acid supporting electrolyte are $0.25 \mathrm{~V}$ and $0.70 \mathrm{~V} v s$. SCE, respectively. After the control-potential adjustments technique is used to complete the sample electrolyses, the final reduction and oxidation (red/ox) solution potentials are typically $0.31 \mathrm{~V}$ and $0.68 \mathrm{~V} v s$. SCE (measured with an uncertainty of $\pm 0.0005 \mathrm{~V}, 1$-sigma). The formal potentials, $\mathrm{E}^{\mathrm{o}}$, for couples $\mathrm{Pu}^{4+} / \mathrm{Pu}^{3+}, \mathrm{NpO}_{2}{ }^{2+} / \mathrm{NpO}_{2}{ }^{+}$, and $\mathrm{Fe}^{3+} / \mathrm{Fe}^{2+}$ in $1 \mathrm{~N}$ sulfuric acid are $0.499 \mathrm{~V}, 0.846 \mathrm{~V}$, and $0.433 \mathrm{~V} v s$. SCE, respectively (measured with an uncertainty of $\pm 0.002 \mathrm{~V}, 1$-sigma). Given these final solution potentials and formal potentials, the fraction electrolyzed for $\mathrm{Pu}, \mathrm{Np}$, and $\mathrm{Fe}$ are expected to be $0.9984,0.002$, and 0.987 , respectively. The interference from iron is nearly quantitative and can be corrected based upon an independent measurement of iron by spectrophotometry or inductively coupled plasma mass spectrometry. The anticipated interference from the $\mathrm{NpO}_{2}{ }^{2+} / \mathrm{NpO}_{2}{ }^{+}$couple should produce a $+0.02 \%$ systematic error for plutonium samples containing neptunium at $10 \%$ of the plutonium concentration. This systematic error decreases as the neptunium contamination decreases.

The Savannah River Site also performs controlled-potential coulometric measurement on neptunium samples for material control and accountability purposes on a routine basis. Then dissolved neptunium oxide samples are measured by controlled-potential coulometry, each aliquot is reduced and oxidized several times to ensure that all $\mathrm{Np}^{4+}$ that is present has been oxidized and all of the neptunium is in the desired oxidation state, $\mathrm{NpO}_{2}{ }^{2+}$ or $\mathrm{NpO}_{2}{ }^{+}$. When measured coulombs of electricity during sample oxidation from the preliminary electrolyses steps are calculated, the neptunium results are typically biased high due to extra electrolysis current from the oxidation of $\mathrm{Np}^{4+}$ to $\mathrm{NpO}_{2}{ }^{2+}$. Once all the neptunium has been converted to $\mathrm{NpO}_{2}{ }^{+}$and $\mathrm{NpO}_{2}{ }^{2+}$, the subsequent coulometric measurement of the neptunium matches, within measurement uncertainty, the expected assay value based on the stoichiometry of the neptunium oxide and its impurity content.

Further investigation will evaluate the effectiveness of:

- Repeating the plutonium sample measurement sequence on the same aliquot to determine if any $\mathrm{Np}^{4+}$ present in the aliquot can be converted to $\mathrm{NpO}_{2}{ }^{2+}$ and $\mathrm{NpO}_{2}{ }^{+}$during the first measurement sequence and thereby eliminating the interference during the second measurement.

- Lowering the end-point current for the sample pre-oxidation step well below the $250 \mu \mathrm{A}$ acceptance criteria, thereby providing more time to oxidize $\mathrm{Np}^{4+}$ during this pre-oxidation step.

- Using a combination of high concentration nitric and sulfuric acid (stronger oxidizing mixture) when fuming the $\mathrm{Pu}: \mathrm{Np}$ aliquots to dryness as sulfate salts in preparation for coulometric measurement. This strong fuming sequence may be repeated as needed, with the objective of selectively oxidizing the $\mathrm{Np}^{4+}$. 


\section{Impact and Limitations}

Conclusions regarding the causes for elevated random error in the plutonium measurement are limited to scientific judgment and speculation that have not been tested or otherwise demonstrated. Such testing is planned and will be reported. The scope of the evaluation was initially limited to aliquots with a maximum $\mathrm{Np}: \mathrm{Pu}$ concentration of $1: 10$ (i.e., $10 \% \mathrm{~Np}$ versus the $\mathrm{Pu}$ content).

The method development plan (MDP) that was written to control the chemical and radiological safety boundaries of the measurement activity reported herein would have allowed an $\mathrm{Np}: \mathrm{Pu}$ concentration of 1:5 (20\%) to be tested, if desired. All work control documents (MDP and analytical procedures) had been screened by the laboratory facility engineering organization using the Unreviewed Safety Question (USQ) process based upon the DOE-approved safety basis and authorization agreement for the SRS FH-Area Laboratory. All planned activities described herein were approved prior to beginning any measurement activities. The method development plan and technical task request documents are included in the Appendices section of this report. Cited procedures are available through the SRS Record Management organization.

\section{Conclusions or Recommendations}

The presence of neptunium in plutonium aliquots significantly increased the random uncertainty and outlier rate associated with the plutonium coulometric measurement performed in accordance with SRS procedures and ISO12183:2005. However, the presence of neptunium does not appear to degrade electrode performance and conditioning as evidenced by results from aliquots of pure plutonium that were interspersed during the measurement of the mixed $\mathrm{Pu}: \mathrm{Np}$ aliquots. The pure plutonium aliquots at both the 6-mg and 15-mg levels continued to achieve the historical short-term random uncertainty for the routine coulometric measurement method at these levels.

Lack of adequate control of the neptunium oxidation state during the plutonium aliquot preparation and measurement steps is suspected to be the cause of the elevated random uncertainty. This potential source of plutonium measurement uncertainty will be pursued in a future study. The purification of the neptunium involved converting the neptunium to the $\mathrm{Np}^{4+}$ oxidation state in preparation for column purification. However the single fuming of the neptunium spike in sulfuric acid before adding the plutonium aliquot and the single measurement of the plutonium content without attempting to eliminate $\mathrm{Np}^{4+}$ by electrochemical means appears to be less than adequate at ensuring satisfactory plutonium coulometric measurement results. 


\section{$\underline{\text { References }}$}

1. Technical Task Request, 2008-INNP-FHL-00001, approved January 23, 2008.

2. Measurement Development Plan, MDP-M\&O-FHL-2008-00017, "Authorization to Evaluate SRS Plutonium Controlled-Potential Coulometric (CPC) Method in the presence of 0-20\% Neptunium (versus Plutonium)," approved February 26, 2008.

3. L3.05-10065, Rev. 3, “Coulometry Pu and Np”, March 1, 2001.

4. L3.05-10122, Rev. 0, "Np Separation for Coulometry", as Work Instruction WI-ACL-04009, Rev.0, February 23, 2004.

5. L3.19-10006, Rev. 2, “ICP-MS Analytical \& Measurement Control”, May 4, 2004.

6. L3.19-10012, Rev. 2, “Actinide Analysis by ICP-MS”, January 29, 2004.

7. ISO 12183, “Controlled-potential coulometric assay of plutonium”, 2005.

8. Michael K. Holland and Kenneth Lewis, Analytical Chimica Acta, 149 (1983) 167-173.

\section{$\underline{\text { Appendices }}$}

1. Technical Task Request 2008-INNP-FHL-00001

2. Method Development Plan MDP-M\&O-FHL-2008-00017 (technical work document and authorization) and related documents.

3. Neptunium Spike - Impurity Content by ICP-MS 


\section{Appendix 1. Technical Task Request, Estimate, and Funding Source, Page 1 of 4}

OSR 19-255 (Rev 9-6-2007)

\section{Technical Task Request}

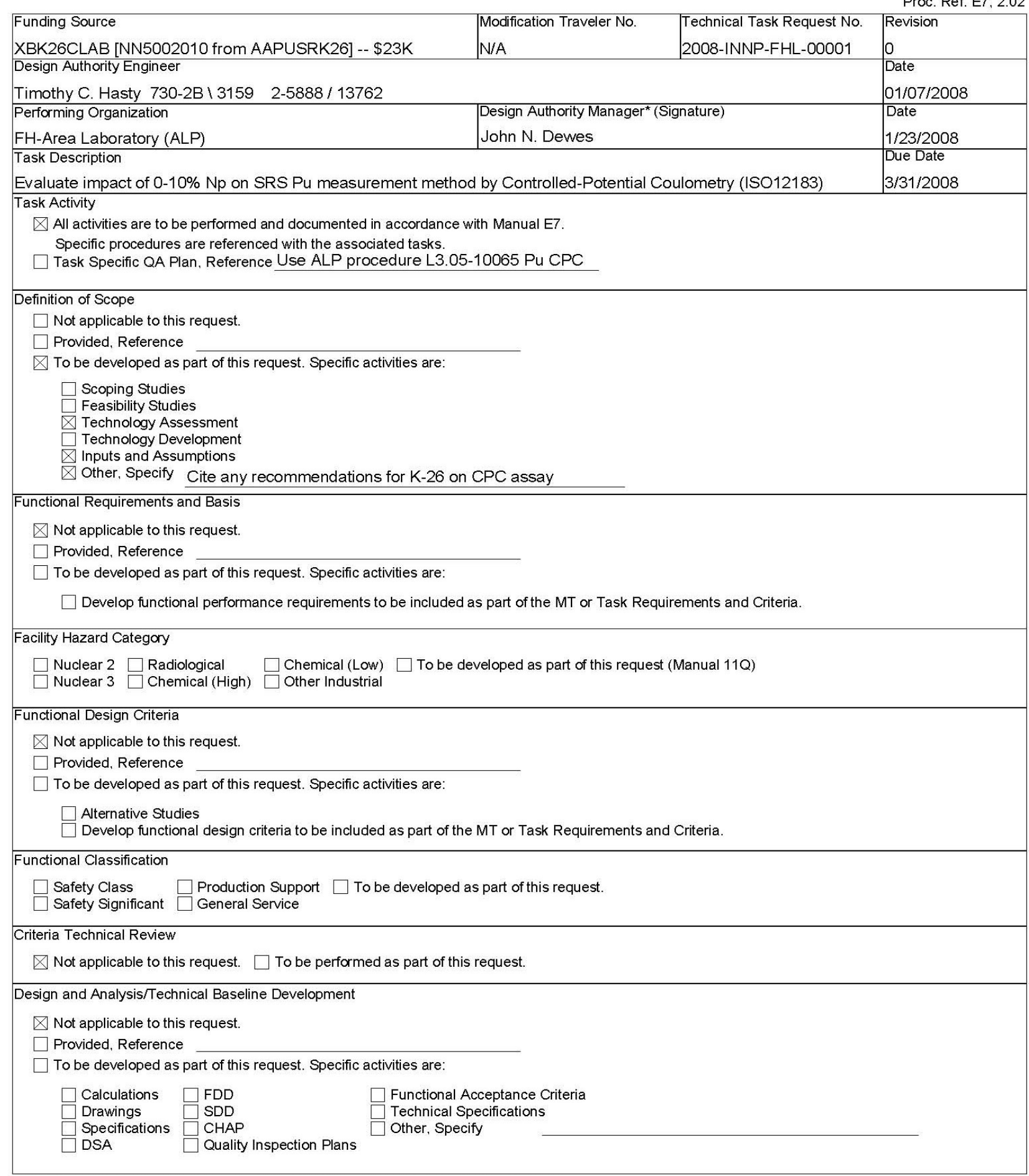

* Design Authority Manager's signature required if request is not associated with an MT. 
Appendix 1. Technical Task Request, Estimate, and Funding Source, Page 2 of 4

OSR 19-255 (Rev 9-6-2007)

\section{Technical Task Request (Continued)}

Proc. Ref. E7, 2.02

\begin{tabular}{l} 
Design and Analysis/Technical Baseline Document Technical Review \\
$\square$ Not applicable to this request. $\square$ To be performed as part of this request. \\
\hline Acceptance Testing \\
$\square$ Acceptance Testing is Not Part of this Request \\
$\square$ Test Procedure Provided, Reference \\
$\square$ Test Procedures to be Developed as Part of this Request \\
$\square$ Test Results Provided, Reference \\
$\square$ Test Results Evaluation Not Part of this Request \\
$\square$ Test Acceptance Report to be Provided as Part of this Request
\end{tabular}

Other Tasks or Clarification

TTR: 2008-INNP-FHL-00001

Measure Pu by controlled-potential coulometry use SRS procedures on samples containing $0-10 \%$ Np versus the Pu measured. Perform sufficient replicate measurements to effectively evaluate the measurement method and its performance. Document results from this evaluation in a document that can be referenced.

It is acceptable to use SRS prepared aliquots of LANL plutonium metal standard exchange materials that are spiked with dissolved SRS neptunium.

For additional details related to executing this request for analytical services and its estimated cost, refer to the attached document prepared by $\mathrm{M}$. $\mathrm{K}$. Holland, ALP chemist, and reviewed by S. T. Nichols, FH-Lab chemist.

Note: On page 1 of this TTR, Facility Hazard Category and Functional Classification are N/A for this TTR and are intentionally not answered.

Other Reviews/Reports Required?

$\square$ No $\square$ Yes, Specify Lab to report measurement results in a document that can be referenced.

\begin{tabular}{|l|l|}
\hline Technical Agency & Name (Print)
\end{tabular}

\begin{tabular}{l|l} 
FH-Area Laboratory & Janice L. Lawson, 772-Fl124 2-3632/17631
\end{tabular}

\begin{tabular}{|l|l|l|l|l}
\hline Acceptance of Task (Signature of Technical Agency Manager) & Date
\end{tabular}

Closure/Deliverables Provided

\begin{tabular}{|l|l|}
\hline Design Authority Engineer & Date \\
\hline Design Authority Manager* & Date \\
\hline
\end{tabular}

* Design Authority Manager's signature required if request is not associated with an MT. 
Appendix 1. Technical Task Request, Estimate, and Funding Source, Page 3 of 4

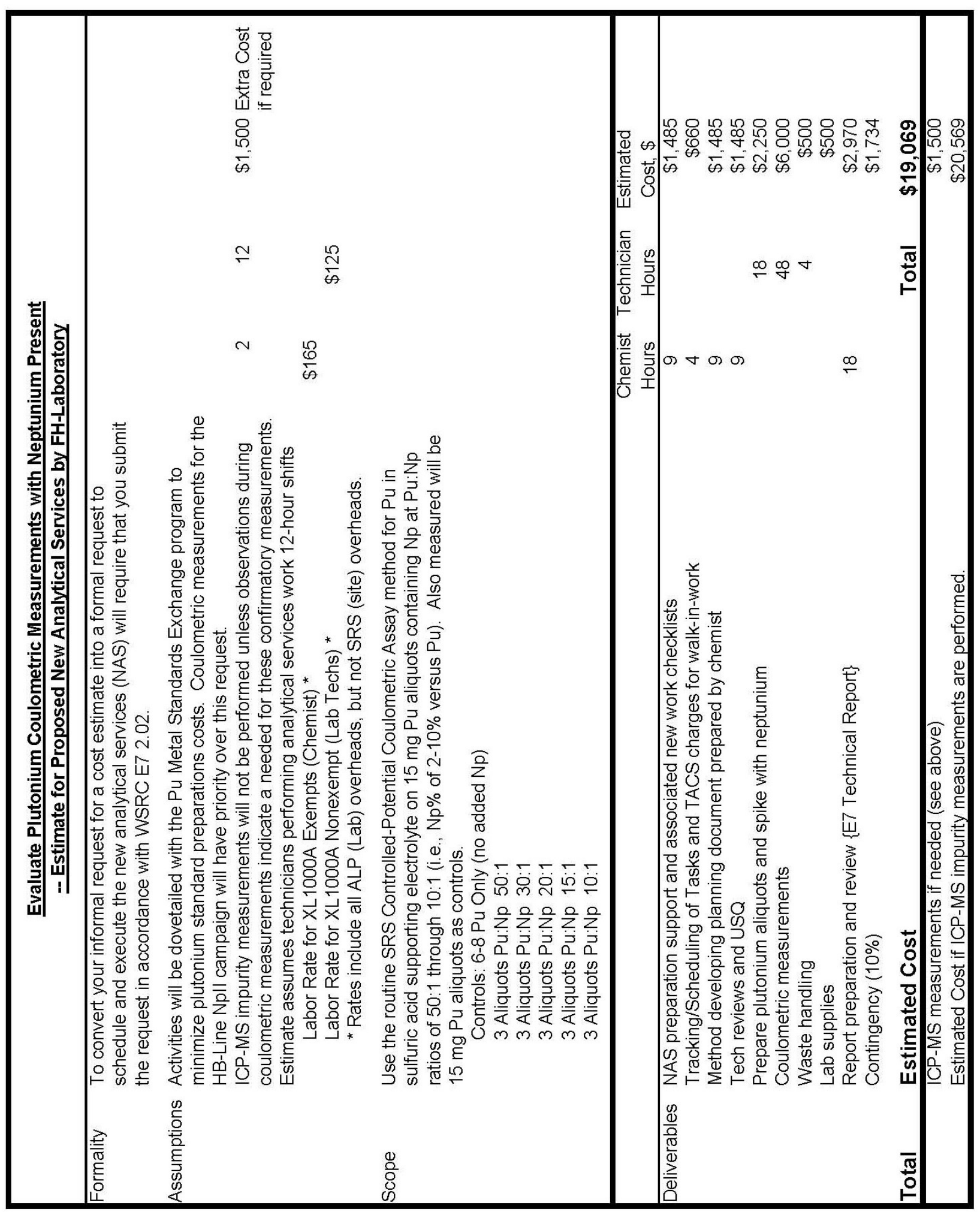

Page 13 of 24 
Appendix 1. Technical Task Request, Estimate, and Funding Source, Page 4 of 4

$$
\begin{aligned}
& \text { Thom as Friel/WSRC/Srs } \\
& \text { 01/09/2008 01:06 PM }
\end{aligned}
$$

\author{
To Timothy Hasty/WSRC/Srs@Srs \\ cc John Dewes/WSRC/Srs@srs, Michael \\ Holland/WSRC/Srs@srs \\ bcc \\ Subject Re: New Codes $\square$
}

The following three activity codes are now open in IBARS effective 1/7/08: XBK26CLAB, XBNNNCSIT, and XBNNNISIT.

Timothy Hasty/WSRC/Srs



\author{
To Thomas Friel/WSRC/Srs@srs \\ cc John Dewes/WSRC/Srs@srs, Michael \\ Holland/WSRC/Srs@Srs \\ Subject New Codes
}

Tom, I need three new codes for labor and materials

NN5002010

XBK26CLAB \$23K CLAB coulometry support move funds from AAPUSRK26. This may need to be a WAD since it is for Analytical Laboratory personnel to do some tests for us.

NN4004020

XBNNNCSIT \$24K CSI support link to ECl 1801

XBNNNISIT \$20K ISIT support link to $\mathrm{ECl} 1801$

Thanks,

Tim

International Nonproliferation Program

Savannah River Site

803-952-5888 (phone)

803-952-5845 (fax. please call if you send one.)

timothy.hasty@srs.gov 
Appendix 2. Method Development Plan \& Related Documents, Page 1 of 9

METHODS DEVELOPMENT PLANNING PROCESS

ADMINISTRATIVE
PROCEDURE:

REVISION:

PAGE:
L3.26-05011

Attachment 3

Method Development Planning Form "Typical"

Page 1 of 3

Date $1 / 31 / 2008$

Document Number MDP-M\&)-FHL-2008-00017

Method Development Plan

1. Define Scope

Evaluate routine $\mathrm{Pu}$ coulometric method (L3.05-10065, "Pu/Np by CPC") for neptunium interference up to $20 \% \mathrm{~Np}$ vs. $\mathrm{Pu}$ (for routine $15 \mathrm{mg} \mathrm{Pu}$ aliquot range) is authorized. The coulometer routinely measures $\mathrm{Pu}$ or $\mathrm{Np}$ using a very similar methodology. Np should not be an interference for $\mathrm{Pu}$ measurements in sulfuric acid. $\mathrm{Pu}$ aliquots will be prepared using the routine preparation process and $\mathrm{Np}$ will be added by volume or by weight (electronic pipette or balance in the desired amount to cover the range from $0-20 \% \mathrm{~Np}$ vs. Pu in the aliquots.

2. Identify hazards (AHA, Engineering Review, etc.)

A. References (AHA, etc.)

- The existing AHA for the CPC Pu/Np method bounds this MDP activity.

- TTR\# 2008-INNP-FHL-00001 (copy attached)

B. Existing Procedures

- L3.05-10065

- WI-ACL-04-009 Rev.0 [Np purification] 
Appendix 2. Method Development Plan \& Related Documents, Page 2 of 9

METHODS DEVELOPMENT PLANNING PROCESS

ADMINISTRATIVE

PROCEDURE:

L3.26-05011

REVISION:

PAGE:

7 OF 9

Attachment 3

Method Development Planning Form "Typical”

Page 2 of 3

3. Develop / Implement Controls

\section{A. Safe Boundaries Summary}

- Comply with L3.05-10065 controls for preparing, handling, and measuring Pu \& Np by CPC.

- Np aliquots may be prepared by volume using routine procedure for using electronic pipettes to add the $\mathrm{Np}$ to the $\mathrm{Pu}$ aliquot (or vice versa). Electronic pipetting is routine in numerous $A L$ (FH-Lab) analytical procedures.

- All data will be reviewed $b$ the CTF before reporting

B. Hazards Summary

- Chemical hazards typical for coulometry

- Radiological hazards typical for coulometry

- Industrial harards typical for coulometry

\section{Plan Readiness}

A. Steps of plan are attached:

Yor N

WFt.

CTF Initials

B. AHA complete / approved: New AHA not required.

C. Engineering review complete:

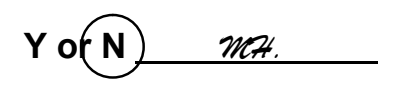

CTF Initials

D. Peer review complete: by S. T. Nichols

Yor N_sTh

CTF Initials

E. Management authorization obtained:

Yor N WAt.

CTF Initials

F. Pre-Job Briefing completed:

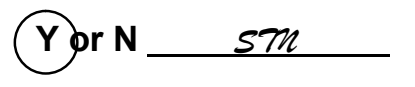

CTF Initials

Yor N_sT

CTF Initials

CTF $=$ Cognizant Technical Function for MDP is scientist or chemist. 
Appendix 2. Method Development Plan \& Related Documents, Page 3 of 9

\section{METHODS DEVELOPMENT PLANNING PROCESS}

Attachment 3, Cont.

Method Development Planning Form "Typical”

Page 3 of 3

5. Review and Authorization of MDP

MDP Peer Reviewed by CTF:

SHELDON NIIHOLS COUCOMETRY CTF Print Name

Title

Signature

$\frac{2 / 14 / 08}{\text { Date }}$

MDP Authorized by Workgroup Manager:

Janice Lauson Print Name

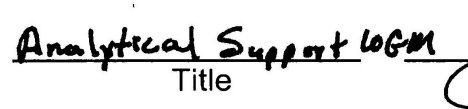

MDP Authorized by Lab Manager:

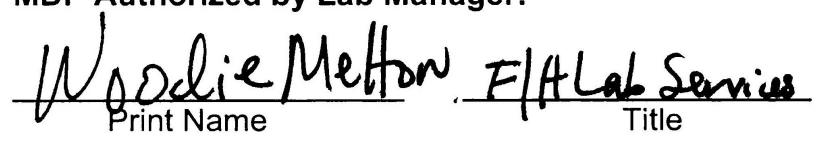

Other Management Approvals:

$\frac{\text { Tery J. P.fer }}{\text { Rco Print Name }}$
Engineering Print Name

G.J. Wimklez

Facility Operations Print Name

$\frac{\text { F/H Lass Safety }+ \text { Health }}{\text { Title }}$

$\frac{\text { Frrea Chret Engeneor }}{\text { Title }}$

$\frac{\text { Facility Maneger }}{\text { Title }}$

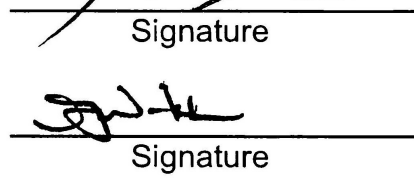

signatwel

$\frac{2 / 21 / 09}{\text { Date }}$

$\frac{2 / 21 / 08}{\text { Date }}$

$\frac{2 / 26 / 08}{\text { Date }}$

6. Feedback Summary

No Issues with MDP planning or execution.

This MDP was able to be used as planned without issues with execution.

Refer to Technical Report WSRC-STI-2008-00238 for analytical results.

This MDP will be used for the planned further studies documented in WSRC-STI-200800238. M. K. Halland 5/812008. 
Appendix 2. Method Development Plan \& Related Documents, Page 4 of 9

Method Development Planning (technical work document)

MDP-M\&O-FHL-2008-00017

Authorization to Evaluate SRS Plutonium Controlled-Potential Coulometric (CPC) Method in the presence of 0-20\% Neptunium (versus Plutonium)

$\underline{\text { Starting Materials }}$

- Neptunium standard solution prepared from one purified Np-CPC QC synthetic. [Routine Np CPC QC aliquot, diluted to a known volume].

- Pu QC solution (routine Pu CPC aliquot size per L3.05-10065) prepared from characterized LANL PMSE metal. QC vials supplied by standards group, dipped in accordance with existing procedures.

Instructions [Steps 1 and 2 can be performed (and repeated) in any order.]

1. Prepare each test aliquot for $\mathrm{Pu} \mathrm{CPC}$ measurement:

- Add desired quantity of $\mathrm{Np}$ solution by volume (pipet).

- Add desired quantity of Pu by weight per L3.5-10065 (nominally $15 \mathrm{mg} \mathrm{Pu}$ aliquot).

- Fume to dryness in $\mathrm{H}_{2} \mathrm{SO}_{4}$, twice per L3.5-10065.

2. Prepare routine Pu QC aliquots (no added Np) by weight per L3.5-10065.

- Fume to dryness in $\mathrm{H}_{2} \mathrm{SO}_{4}$, twice per L3.5-10065.

3. Measure Pu by CPC per L3.5-10065, using Pu QC's to bracket test aliquot measurements, per L3.5-10065.

- Example of sequence with QC bracketing:

$\begin{array}{lll}\text { Aliquot } & \begin{array}{l}\text { Planned Ratio } \\ \text { (SME/CTF may adjust } \\ \text { within MDP bounds) }\end{array} & \begin{array}{l}\text { Corresponding } \\ \text { Np with 15 }\end{array} \\ \text { Pu QC } & & \\ \text { PuNp 1A } & 1=\text { Pu:Np at 50:1 } & 0.3 \mathrm{mg} \mathrm{Np} \\ \text { PuNp 2A } & 2=\text { Pu:Np at 30:1 } & 0.5 \mathrm{mg} \mathrm{Np} \\ \text { PuNp 3A } & 3=\text { Pu:Np at } 20: 1 & 0.75 \mathrm{mg} \mathrm{Np} \\ \text { PuNp 4A } & 4=P u: N p \text { at } 15: 1 & 1.0 \mathrm{mg} \mathrm{Np} \\ \text { PuNp 5A } & 5=\text { Pu:Np at } 10: 1 & 1.5 \mathrm{mg} \mathrm{Np}\end{array}$

$\mathrm{Pu} \mathrm{QC}$

- The " $\mathrm{A}$ " designation is the $1^{\text {st }}$ aliquot prepared at the indicated ratio. The $2^{\text {nd }}$ set of bracketed test solutions will to be measured will be the "B" aliquots, each at a different $\mathrm{Pu}: \mathrm{Np}$ ratio. The exact aliquot sequence within a $\mathrm{QC}$ bracket is not critical. For example the sequence could also be $2 \mathrm{~A}, 4 \mathrm{~A}, 3 \mathrm{~A}, 1 \mathrm{~A}, 5 \mathrm{~A}$, and can be different on subsequent days.

4. Repeat the Pu by CPC measures on "B" aliquots per L3.5-10065.

5. Repeat the Pu by CPC measures on "C" aliquots per L3.5-10065.

6. If directed by the CTF, Repeat the Pu by CPC measures on " $D$ " aliquots per L3.5-10065.

This MDP may be used for additional evaluation of the Pu CPC measurement method with Np present up to a Pu:Np ratio of 5:1 (20\% Np) without re-approval of the MDP. 
Appendix 2. Method Development Plan \& Related Documents, Page 5 of 9

\begin{tabular}{|c|c|c|}
\hline \multicolumn{3}{|l|}{$\begin{array}{l}\text { Oß3R } 39-31 \text { (Rev 5-31-2005) } \\
\text { Páge } 1 \text { of } 3\end{array}$} \\
\hline $\begin{array}{l}\text { Work Package/Technical Work Document } \\
\text { TTR2008-INNP-FHL-00001 }\end{array}$ & $\begin{array}{l}\text { RWP No. } \\
\text { O8-CLB-002 }\end{array}$ & \begin{tabular}{l|l} 
Work Location \\
$772-\mathrm{F}$ and $772-1 \mathrm{~F}$
\end{tabular} \\
\hline \multirow{2}{*}{\multicolumn{3}{|c|}{$\begin{array}{l}\text { Sheldon Nichols } \\
\text { Job Scope }\end{array}$}} \\
\hline & & \\
\hline \multicolumn{3}{|l|}{$\begin{array}{l}\text { Pu/Np Ratio Coulometry Runs, Per MDP-M\&O-FHL-2008-00017 } \\
\text { AHA Required? }\end{array}$} \\
\hline \multicolumn{3}{|l|}{$\begin{array}{l}\text { AHA Required? } \\
\text { Yes } \odot \text { No If YES, enter AHA No. N/A }\end{array}$} \\
\hline \multicolumn{3}{|c|}{$\begin{array}{l}\text { Check YES (if applicable to job) or N/A if topic was not covered in briefing. Encourage worker participation and include comments as applicable. } \\
\text { Mandatory items for discussion are denoted with an asterisk }\left({ }^{*}\right) \text {. }\end{array}$} \\
\hline A. *Scope and Complexity of Work & Yes & Comments \\
\hline Review TWDs, permits, procedures, work instructions, etc. & $\bigcirc$ Yes $\bullet N / A$ & \\
\hline \multicolumn{3}{|l|}{ B. Safety Requirements } \\
\hline IH Hazards, Controls, Monitoring, and PPE Requirements & - Yes $\bigcirc \mathrm{N} / \mathrm{A}$ & Don appropriate PPE per RWP \\
\hline Physical Hazards & $\bigcirc$ Yes $\odot \mathrm{N} / \mathrm{A}$ & \\
\hline Lifting Techniques & $\bigcirc$ Yes $\bigcirc \mathrm{N} / \mathrm{A}$ & \\
\hline Barricades & $\bigcirc$ Yes $○$ N/A & \\
\hline Pinch Points/Sharp Objects & $\bigcirc$ Yes $\bigcirc N / A$ & \\
\hline Lockouts or Isolations & $\bigcirc$ Yes $\odot N / A$ & \\
\hline Heat Stress (work/rest regimen)/Adverse Weather Conditions & $\bigcirc$ Yes $\bigcirc \mathrm{N} / \mathrm{A}$ & \\
\hline Slipping and Tripping Hazards & $\bigcirc$ Yes $\odot$ N/A & \\
\hline Fitness for Duty & - Yes $\bigcirc \mathrm{N} / \mathrm{A}$ & Physically/Mentally Fit and Focused on the task \\
\hline Ladders or Scaffolding Usage and Elevated Work & $\bigcirc$ Yes $\odot$ N/A & \\
\hline Safety Items Identified on the AHA & $\bigcirc$ Yes $\odot \mathrm{N} / \mathrm{A}$ & \\
\hline Stop Work Authority/Time Out & Yes $\bigcirc \mathrm{N} / \mathrm{A}$ & Each individual has authority to stop work/time out \\
\hline Electrical Safety and Stored Energy & $\bigcirc$ Yes $\odot N / A$ & \\
\hline Fire Suppression Systems & $\bigcirc$ Yes $\odot N / A$ & \\
\hline \multicolumn{3}{|l|}{ C. *Radiological Conditions } \\
\hline Review All Sections of the RWP and ALARA Review (if applicable) & - Yes $\bigcirc \mathrm{N} / \mathrm{A}$ & RWP 08-CLB-002 \\
\hline Current and Expected Radiological Conditions & - Yes $\bigcirc \mathrm{N} / \mathrm{A}$ & \\
\hline High and Low Dose Areas & - Yes ON/A & Per RWP 08-CLB-002 \\
\hline Hot Spot Locations & $\bigcirc$ Yes $\odot \mathrm{N} / \mathrm{A}$ & \\
\hline \multicolumn{3}{|l|}{ D. *Radiological Controls } \\
\hline Radiological Boundaries and Barricades & - Yes $\bigcirc \mathrm{N} / \mathrm{A}$ & \\
\hline Containment Requirements & - Yes ON/A & Follow current radiological control practices \\
\hline RWP Suspension Guides & - Yes ON/A & Adhere to RWP \\
\hline Radcon Action Steps and Hold Points & $\bigcirc$ Yes $\bigcirc \mathrm{N} / \mathrm{A}$ & \\
\hline Use of Temporary Shielding & $\bigcirc$ Yes $\odot \mathrm{N} / \mathrm{A}$ & \\
\hline Contaimination Control Methods & - Yes $\bigcirc \mathrm{N} / \mathrm{A}$ & Follow current radiological control practices \\
\hline Exposure Limits for Job & $\bigcirc$ Yes $\odot$ N/A & \\
\hline
\end{tabular}


Appendix 2. Method Development Plan \& Related Documents, Page 6 of 9

\begin{tabular}{|c|c|c|}
\hline \multicolumn{3}{|l|}{$\begin{array}{l}\text { OSR 39-31 (Rev 5-31-2005) } \\
\text { Page } 2 \text { of } 3\end{array}$} \\
\hline Work Package/Technical Work Document & \multirow{2}{*}{$\begin{array}{l}\text { RWP No. } \\
\text { O8-CLB-002 }\end{array}$} & \multirow{3}{*}{$\begin{array}{r}\text { Date } \\
\text { Comments }\end{array}$} \\
\hline TTR2008-INNP-FHL-00001 & & \\
\hline E. *Special Radiological Controls & Yes $\quad$ N/A & \\
\hline Protective Clothing Requirements & $\bigcirc$ Yes $\odot$ N/A & \\
\hline Special Donning and Removal Techniques/Glove Changes & $\bigcirc$ Yes $\odot$ N/A & \\
\hline Dosimetry Requirements & - Yes $\bigcirc \mathrm{N} / \mathrm{A}$ & TLD per RMP 08-CLB-002 \\
\hline Respiratory Requirements & $\bigcirc$ Yes $\odot$ N/A & \\
\hline Time Keeper Requirements & $\bigcirc$ Yes $\odot$ N/A & \\
\hline Requirements for Using HEPA Filtered Vacuum Cleaners & $\bigcirc$ Yes $\odot N / A$ & \\
\hline \multicolumn{3}{|l|}{ F. Waste Minimization } \\
\hline Waste/Laundry Receptacles at the Job Site & $\bigcirc$ Yes $\odot$ N/A & \\
\hline Restrict Supplies Entering Area to Those Needed for Work & Yes $\bigcirc \mathrm{N} / \mathrm{A}$ & Unpackage supplies prior to transporting into CA \\
\hline $\begin{array}{l}\text { Restrict Quantities of Hazardous Material Entering Area and Take } \\
\text { Measures to Prevent Cross Contamination }\end{array}$ & $\bigcirc$ Yes $\bigcirc$ N/A & \\
\hline Discuss Waste Stream Worksheet & $\bigcirc$ Yes $\odot$ N/A & \\
\hline $\begin{array}{l}\text { Waste Containers are Adequate for Waste (liquids, heavy } \\
\text { objects, etc.). Do not toss or drag waste bags across floor. }\end{array}$ & $\bigcirc$ Yes $\odot N / A$ & \\
\hline $\begin{array}{l}\text { Use and Disposal of Hazardous/Mixed-Hazardous Wastes (oils, } \\
\text { chemicals, liquids, etc.) }\end{array}$ & $\bigcirc$ Yes $\odot$ N/A & \\
\hline Survey Requirements for Material Release & $\bigcirc$ Yes $\odot \mathrm{N} / \mathrm{A}$ & \\
\hline $\begin{array}{l}\text { Wrap Tools and Sharp Objects to Prevent Puncturing } \\
\text { Containment and Waste Bags }\end{array}$ & $\bigcirc$ Yes $\odot$ N/A & \\
\hline Requirements for Transporting Rad materials to/from Job & $\bigcirc$ Yes $\odot \mathrm{N} / \mathrm{A}$ & \\
\hline \multicolumn{3}{|l|}{ G. ${ }^{\star}$ Communication and Coordination } \\
\hline Discuss Training and Qualifications Requirements & $\bigcirc$ Yes $\odot$ N/A & \\
\hline Communication Methods to be Utilized & $\bigcirc$ Yes $\bigcirc \mathrm{N} / \mathrm{A}$ & \\
\hline Coordination with Other Work Groups & $\bigcirc$ Yes $\odot$ N/A & \\
\hline Standing Orders, Lessons Learned, etc., that may Impact Task & $\bigcirc$ Yes $\odot$ N/A & \\
\hline \multicolumn{3}{|l|}{ H. *Housekeeping and Final Cleanup } \\
\hline Housekeeping Responsibilities (area cleanup/waste removal) & - Yes $\bigcirc \mathrm{N} / \mathrm{A}$ & Follow waste handling protocol \\
\hline $\begin{array}{l}\text { Bag items for future use and apply "DO NOT DISCARD" tags. } \\
\text { RCO to survey and tag for transport. }\end{array}$ & $\bigcirc$ Yes $\odot \mathrm{N} / \mathrm{A}$ & \\
\hline Decon Responsibilities. RCO Survey and Depost. & $\bigcirc$ Yes $\odot \mathrm{N} / \mathrm{A}$ & \\
\hline Containment Removal and Return Area to Normal & $\bigcirc$ Yes $\odot \mathrm{N} / \mathrm{A}$ & \\
\hline \multicolumn{3}{|l|}{ I. ^Emergency Response Provisions } \\
\hline CAM Alarms & - Yes $\bigcirc \mathrm{N} / \mathrm{A}$ & Evacuate/Notify SOM/RCO/FLM \\
\hline ARM Alarms & - Yes $\bigcirc \mathrm{N} / \mathrm{A}$ & Respond to alarms per procedure \\
\hline NIM Alarms & $\bigcirc$ Yes $\odot$ N/A & \\
\hline EPD Alarms & $\bigcirc$ Yes $\odot$ N/A & \\
\hline Evacuation Route/Rally Point & - Yes $\bigcirc \mathrm{N} / \mathrm{A}$ & Respond to all alarm announcements as required \\
\hline Loss of Breathing Air & $\bigcirc$ Yes $\odot$ N/A & \\
\hline Loss of Ventilation & - Yes $\bigcirc \mathrm{N} / \mathrm{A}$ & Evacuate/Notify SOM/RCO/FLM \\
\hline Abnormal/Degrading/Unexpected Conditions (specify) & $\bigcirc$ Yes $\odot N / A$ & \\
\hline
\end{tabular}


WSRC-STI-2008-00238

Revision 0

Appendix 2. Method Development Plan \& Related Documents, Page 7 of 9

OSR 39-31 (Rev 5-31-2005)
Page 3 of 3

Pre-Job Briefing Attendance Roster

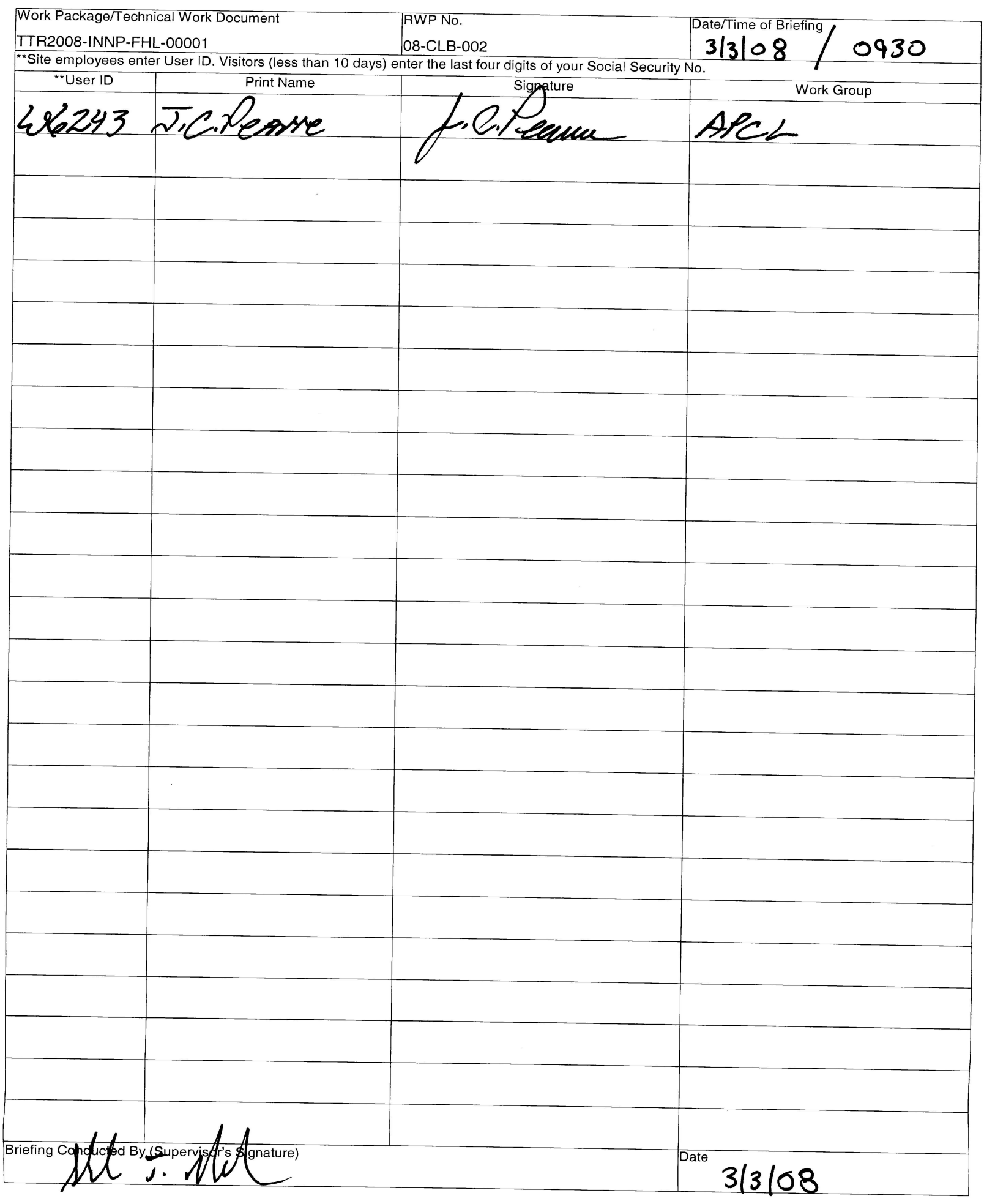

Page 21 of 24 
Appendix 2. Method Development Plan \& Related Documents, Page 8 of 9

\section{UNREVIEWED SAFETY QUESTION PROCESS}

\section{USQ SCREENING - PART A}

Title: Scope M\&O-FHL-2008-00017, January 31, 2008, Coulometry for Pu spiked with Np

Description of Proposed Activity* (PA) (or Discovery): The Proposed Action (PA) is performing coulometry for Pu solutions spiked with $\mathrm{Np}$. Both $\mathrm{Pu}$ and $\mathrm{Np}$ are routinely analyzed individually by this method. This activity uses existing inventory and know radionuclides with instruments currently in the facility.

* Include intermediate configurations and impacts on other facilities which might result from the proposed activity.

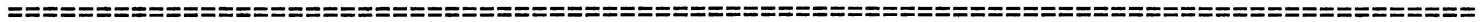

1. Is the Proposed Activity a change to TSRs?

Justification and References: WSRC-TS-95-18, Technical Safety Requirements Savannah River Site F-Area Central Laboratory Facility, Buildings $772-\mathrm{F}, 772-1 \mathrm{~F}$, and $772-4 \mathrm{~F}(\mathrm{U}) "$ ", revision $5,11 / 06$. The PA does not challenge, perform, or modify any of the requirements.

If YES, prior DOE approval through the TSR change process is required, no further USQ screening or evaluation is required. If $\mathrm{NO}$, continue with screening.

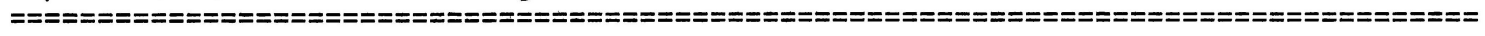

2.

Does the Proposed Activity involve:

a. Change to the facility as described in the Documented Safety Analysis?

[ ] YES [ $x$ ] NO

b. Change to procedures as described in the Documented Safety Analysis?

[ ]YES [ $x$ ] NO

c. Test or experiment not described in the Documented Safety Analysis?

[ ] YES [ $x$ ] NO

d. Analytical errors, omissions, or deficiencies in the Documented Safety Analysis?

[ ] YES [ $x$ ] NO

If question a, b, c, or $d$ is answered "YES", justification below is not required, complete Blocks 3 and 4 and complete a USQ Safety Evaluation (Block 5).

\section{Supporting Information}

References: TSR listed in section 1, WSRC-SA-96-26, "Central Laboratory Facility - Buildings 772-F, 772-1F, and 7724F Safety Analysis Report (U)", revision 4, 11/06, USQ-FHLAB-2004-044, USQ-FHLAB-2006-088, USQ-FHLAB-2006122, USQ-FHLAB-2007-007, and USQ-FHLAB-2008-008.

For configuration control: WSRC-SA-96-26, "Central Laboratory Facility - Buildings 772-F, 772-1F, and 772-4F Safety Analysis Report (U)", revision 5A, 7/07, WSRC-TS-95-18, Technical Safety Requirements Savannah River Site F-Area Central Laboratory Facility, Buildings 772-F, 772-1F, and 772-4F (U)", revision 6, 7/07, USQ-FHLAB-2005-030, USQFHLAB-2005-082, USQ-FHLAB-2006-017, USQ-FHLAB-2006-061, USQ-FHLAB-2007-085, USQ-FHLAB-2007-160, and USQ-FHLAB-2007-171.

Justification (Required if response to ALL questions above is "NO"): The PA uses existing approved procedures, WIACL-04-009 and L3.05-10065. The scoping document provides additional detail to combine Np and Pu for analysis under the current procedure. Aspects of the analytical process are discussed in Chapter 2, Section 2.5.1. Table 2.5-1 details typical analyses. The list in the table is provided as a typical description not specific authorization for exclusive analytical techniques. The procedures are not specifically listed in the SAR. Altering an analytical process in accordance with facility expectations and requirements is not a change to a procedure described in the SAR. Neither analytical capability nor the analytical processes in $\mathrm{F} / \mathrm{H}$ Lab are credited for prevention or mitigation of design basis accidents. The PA does not involve manipulation of facility system or the authorization for changes to the chemical or radionuclide inventory. The PA is not a change to the facility as described in the SAR. The change to the analytical process is not a test or experiment. During the review no issues were noted and the PA is not related to an analytical deficiency in the SAR analysis. The PA does not challenge the DSA listed above. 
Appendix 2. Method Development Plan \& Related Documents, Page 9 of 9

\section{UNREVIEWED SAFETY QUESTION PROCESS}

\section{USQ-FHLAB-2008-039}

\section{Page 2 of 2}

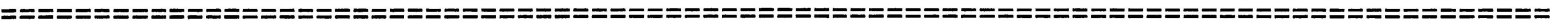

3. SCREENING ORIGINATOR

a. Is a USQE required? (If "YES", submit to EO for USQE) [ ] YES [ $\mathrm{x}$ ] NO

b. Does the PA require a change to the DSA in accordance with 11Q? (If yes, forward a copy of USQS to Regulatory Programs) [ ] YES [ $x$ ] NO

c. Does this PA eliminate or modify a DSA identified Non-SC/SS Defense-in-Depth [ ] YES [ $x$ ] NO Control? (If yes, forward a copy of the USQS/USQE to Regulatory Programs for transmittal to DOE) [For CLAB, only the fire detection/suppression systems are included]

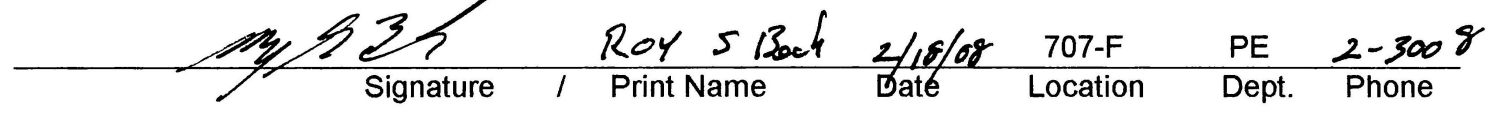



4. SCREENING REVIEWER

Is a USQE required? (If "YES", and a USQE has not been completed, return to EO)

[ ]YES \NO

Comments: None Returned to EO for: [ ] Initiation of $\quad$ IISAF Prncsess

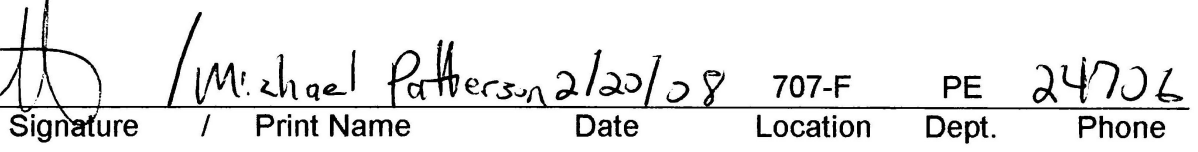


Appendix 3. Neptunium Spike - Impurity Content by ICP-MS

\begin{tabular}{|c|c|c|c|c|}
\hline Element & $\begin{array}{l}\text { ug/L Soln } \\
\text { (ppb) }\end{array}$ & $\begin{array}{l}\mathrm{ug} / \mathrm{g} \mathrm{Np} \\
(\mathrm{ppm})\end{array}$ & $\begin{array}{l}\text { ug/g Pu for } \\
\text { 10:1 Pu:Np }\end{array}$ & \\
\hline $\mathrm{Li}$ & ND & $\mathrm{ND}$ & ND & \\
\hline $\mathrm{Be}$ & $<0.1$ & $<0.04$ & $<0.004$ & \\
\hline B & 3548 & 1228 & 123 & \\
\hline $\mathrm{Na}$ & 5626 & 1948 & 195 & \\
\hline $\mathrm{Mg}$ & 123 & 43 & 4 & \\
\hline $\mathrm{Al}$ & 2328 & 806 & 81 & \\
\hline $\mathrm{Si}$ & 5104 & 1767 & 177 & \\
\hline$P$ & 145 & 50 & 5 & \\
\hline $\mathrm{K}$ & 508 & 176 & 18 & \\
\hline $\mathrm{Ca}$ & ND & ND & ND & \\
\hline $\mathrm{Ti}$ & 7 & 2 & 0.2 & \\
\hline V & $<1.0$ & $<0.4$ & $<0.04$ & \\
\hline $\mathrm{Cr}$ & 22 & 8 & 0.8 & \\
\hline $\mathrm{Mn}$ & 2 & 0.7 & 0.1 & \\
\hline $\mathrm{Fe}$ & 1438 & 498 & 50 & * \\
\hline Co & $<1.0$ & $<0.4$ & $<0.04$ & \\
\hline $\mathrm{Ni}$ & 11 & 4 & 0.4 & \\
\hline $\mathrm{Cu}$ & 7 & 2 & 0.2 & \\
\hline $\mathrm{Zn}$ & 155 & 54 & 5 & \\
\hline $\mathrm{Ga}$ & 1 & 0.4 & 0.04 & \\
\hline As & $<1.0$ & $<0.4$ & $<0.04$ & \\
\hline $\mathrm{Se}$ & $<0.1$ & $<0.04$ & $<0.004$ & \\
\hline $\mathrm{Zr}$ & 17 & 6 & 0.6 & \\
\hline $\mathrm{Nb}$ & $<0.1$ & $<0.04$ & $<0.004$ & \\
\hline Mo & 3 & 1 & 0.1 & \\
\hline Tc & ND & ND & ND & \\
\hline $\mathrm{Ag}$ & $<0.1$ & $<0.04$ & $<0.004$ & \\
\hline $\mathrm{Cd}$ & $<1.0$ & $<0.4$ & $<0.04$ & \\
\hline Sn & 790 & 273 & 27 & \\
\hline Cs & 4 & 2 & 0.2 & \\
\hline $\mathrm{Ba}$ & 6 & 2 & 0.2 & \\
\hline La & $<1.0$ & $<0.4$ & $<0.04$ & \\
\hline $\mathrm{Ce}$ & 16 & 6 & 0.6 & \\
\hline $\mathrm{Sm}$ & $<0.1$ & $<0.04$ & $<0.004$ & \\
\hline $\mathrm{Eu}$ & $<0.1$ & $<0.04$ & $<0.004$ & \\
\hline $\mathrm{Gd}$ & $<1.0$ & $<0.4$ & $<0.04$ & \\
\hline Dy & $<0.1$ & $<0.04$ & $<0.004$ & \\
\hline $\mathrm{Hf}$ & $<1.0$ & $<0.4$ & $<0.04$ & \\
\hline $\mathrm{Ta}$ & $<0.1$ & $<0.04$ & $<0.004$ & \\
\hline W & $<1.0$ & $<0.4$ & $<0.04$ & \\
\hline $\mathrm{Hg}$ & ND & ND & ND & \\
\hline $\mathrm{Pb}$ & 5 & 2 & 0.2 & \\
\hline Th & 27338 & 9464 & 946 & \\
\hline U & 2115 & 732 & 73 & \\
\hline $\mathrm{Np}$ & 2888495 & --- & --- & \\
\hline $\mathrm{Pu}$ & 9 & 3 & 0.3 & \\
\hline Am & $<0.1$ & $<0.04$ & $<0.004$ & \\
\hline $\mathrm{Cm}$ & $<1.0$ & $<0.4$ & $<0.04$ & \\
\hline $\begin{array}{l}\text { Iron at } 5 \\
\text { the pluto }\end{array}$ & $\begin{array}{l}\text { of plutor } \\
y \text { in sulfu }\end{array}$ & $\begin{array}{l}\text { es a }+0 \\
\text { porting } €\end{array}$ & ive bias in & \\
\hline
\end{tabular}

